\title{
Kök Hücreler ve Veteriner Hekimlikte Kullanım Alanları
}

\author{
Osman BULUT' ${ }^{1, a, *}$ Ali BELGE ${ }^{2, b}$ \\ ${ }^{1}$ Muğla Sıtkı Koçman Üniversitesi, Milas Veteriner Fakültesi, Cerrahi Anabilim Dalı, Milas, Muğla, Türkiye \\ ${ }^{2}$ Adnan Menderes Üniversitesi, Veteriner Fakültesi, Cerrahi Anabilim Dalı, Aydin, Türkiye \\ aORCID: 0000-0003-2773-8243, bORCID: 0000-0003-3346-6926
}

Geliş Tarihi: 10.01.2020

Kabul Tarihi: 16.06.2020

\begin{abstract}
Özet: Kök hücreler kendilerini yenileme özelliğine sahip olup, özel koşullar altında farklı hücre tiplerine dönüşebilmektedir. Kök hücreler farklılaşma özelliklerine göre; totipotent kök hücreler, pluripotent kök hücreler ve multipotent kök hücreler olarak sınıflandırılırken, embriyonik ve embriyonik olmayan kök hücreler olmak üzere iki ana gruba ayrılmaktadır. Bu derlemede kök hücrelerin genel özellikleri ile kök hücre tiplerinden bahsedilerek veteriner hekimlikte kullanım alanları hakkında özlü bilgi verilmesi amaçlanmıştır.
\end{abstract}

Anahtar Kelimeler: Kök hücreler, Kök hücre tipleri, Veteriner hekimlik

\section{The Stem Cells and Their Usage In Veterinary Medicine}

Abstract: Stem cells have the ability to regenerate themselves, and when they are induced appropriateoy, can differentiate to many specialized cell types in the body and laboratory environments. Stem cells are classified as totypotent, pluripotent and multipotent stem cells based on their differentiation characteristics. In addition, they are divided into two main groups of embryonic and non-embryonic stem cells. In this review, we aimed to give concise information about general characteristics, stem cell types and their applications in veterinary areas.

Keywords: Stem cells, Stem cell types, Veterinary medicine

\section{Giriş}

Heterojen üreme potansiyeline sahip ve fonksiyonel olarak farklılaşmamış hücre olarak tanımlanan kök hücreler, organizmadaki ilk hücreler olarak bilinmektedir (Şimşek, 2012). Kök hücreler kendilerini yenileme özelliğine sahip olup, özel koşullar altında farklı hücre tiplerine dönüşebilmektedir (Sağsöz ve Ketani, 2008). Temel kök hücre kaynakları; erişkin kök hücreler, kordon kanından elde edilen kök hücreler ve embriyonik kök hücreler şeklinde sıralanmaktadır (Şahin ve ark., 2005).

\section{Kök Hücrelerin Özellikleri}

Kök hücreleri normal hücrelerden ayıran 3 temel özellik bulunmaktadır. Bunlardan ilki normal hücreler sınırlı sayıda çoğalabilirken, kök hücreler sonsuz bölünme ve çoğalma yeteneğine sahiptir. İkincisi normal hücreler bir görevi yapmak üzere özelleşmişken, kök hücreler özelleşmemiş hücrelerdir. Son olarak normal hücreler bir başka hücre tipine farklılaşamazken kök hücreler birçok farklı hücreye dönüşebilmektedirler (Bianco ve ark., 2013). Kök hücrelerin farklı hücre türlerine dönüşebilme özelliğine plastisite adı verilmektedir. Kök hücreler farklılaşma özelliklerine göre; totipotent kök hücreler, pluripotent kök hücreler ve multipotent kök hücreler olarak sınıflandırılmaktadırlar (Gattegno-Ho ve ark., 2012).
Totipotent Kök Hücreler; Totipotent kelime olarak "her şey olma" anlamında kullanılmaktadır. Tüm hücrelere dönüşebilme potansiyeline sahip embriyonal blastula hücresi "totipotent" hücre grubuna dahildir (Kalra ve Tomar, 2014). Bu hücreler; embriyonal hücrelere, embriyonal zarlara, erişkin tüm doku ve organlara farklılaşabilme özelliğine sahiptirler (Karaşahin, 2012).

Pluripotent Kök Hücreler; Fertilizasyonun 5. gününden itibaren, totipotent hücreler değişim göstererek, endoderm ve ektoderm tabakalarını oluştururlar. Yeni oluşan bu yapıya "blastosist" adı verilir. Blastosistin ektoderminden, embriyonun beslenmesi ve solunumunu sağlayacak olan plasenta ile yavruyu saran chorion kesesi gelişirken, endoderm tabakasından göz, kalp, beyin gibi iç organlar ile kaslar ve kemikler gelişir (Thore ve ark., 2008). Blastosistin endodermindeki hücreler pluripotent kök hücreler sınıfına aittir. Bu hücreler erken gelişim döneminde bulunurlar ve organizmada birçok dokunun oluşmasına kaynak oluşturarak vücudun herhangi bir tür hücresine dönüşme yeteneğine sahiptirler. Pluripotent kök hücrelere aynı zamanda embriyonik kök hücreler de denilmektedir (Thomson ve ark., 1998). 
Multipotent Kök Hücreler; Pluripotent kök hücre aşamasından sonraki hücre tipleri multipotent kök hücreler ya da erişkin kök hücreler olarak adlandırılmaktadır. Multipotent kök hücre tipine verilebilecek en iyi örnek hematopoetik kök hücrelerdir (Ural, 2006). Bu hücreler özel koşullar altında çok daha fazla hücre türüne dönüşebilmektedir. Örneğin kan kök hücreleri sinir hücrelerine dönüşebilmektedir. Bununla birlikte multipotent kök hücre tipleri mezenkimal kök hücreler olarak kabul edilmektedir (Thomson ve ark., 1998).

\section{Kök Hücrelerin Sınıflandırılması \\ - Embriyonik kök hücreler \\ - Embriyonik olmayan kök hücreler \\ 1- Erişkin kök hücreleri}

a) Hematopoetik kök hücreleri

$$
\begin{aligned}
& \text { I. Kemik iliği kök hücreler } \\
& \text { II. Periferik kan kök hücreler } \\
& \text { III. Kordon kanı kök hücreler }
\end{aligned}
$$

b) Stromal kök hücreler

c) Organlardaki kök hücreler

2- Fötal kök hücreler

3- Kadavra kök hücreleri (Sağsöz ve Ketani, 2008)

\section{Embriyonik kök hücreler}

Sperm ile yumurtanın döllenmesi sonucu organizmanın ilk hücresi oluşmaktadır. Daha sonra bu ilk hücre bölünerek 2, 4, 8 hücre oluşturur ve sayısını ikiye katlayarak 4 günün sonunda canlı organizmayı meydana getirecek güce sahip olur. Embriyonik kök hücreler blastosit adı verilen ve anne karnında gelişen hücre topluluğundan alınan hücrelerin her biri için ifade edilmektedir (Webster ve ark., 2012). Embriyonik kök hücreler, deneysel olarak yumurtalardan elde edilen embriyolardan alınır. Bu hücreler özel koşullar altında çoğaltılabilmekte ve dondurularak saklanabilmektedir (Thomson ve ark., 1998). Embriyonik kök hücreler hızlı çoğalabilmekte ve organizma için yenilenebilir kaynak oluşturmaktadır (Thore ve ark., 2008). Embriyonik kök hücrelerin yaygın olarak kullanıldığı hastalıklar; karaciğer ve kalp hastalıkları, diyabet, merkezi sinir sistemi hastalıkları şeklinde sıralanabilmektedir (Juopperi, 2012).

\section{Embriyonik olmayan kök hücreler}

\section{Erişkin kök hücreler (postnatal kök hücre)}

Embriyo, sekiz haftalık gelişim evresinden sonra fetüs halini alır ve erişkin kök hücreleri oluşmaya başlar. Erişkin kök hücreler organizmada ölen ya da zarar görmüş hücre tiplerine farklılaşır ve çoğalabilirler. Bu sayede alternatif hücre tipleri olarak görev yapmaktadırlar (Clevers, 2015). Erişkin kök hücreler birçok dokuda bulunurken birçok dokuların oluşumunda da katkıda bulunabilmektedirler (Perin ve ark., 2003). Son yıllarda yapılan çalışmalarda erişkin kök hücrelerin tamamen farklı bir dokunun hücrelerine farklılaşabileceği gösterilmiştir. Bu olaya plastisite adı verilmektedir. Örneğin; kan hücrelerine farklılaşmaya yönlendirilmiş olan hematopoetik kök hücreleri; sinir hücreleri, karaciğer hücreleri ve kalp kası hücrelerine farklılaşabilmektedir. Bu nedenle özellikle kök hücre tedavilerinde erişkin kök hücrelerin kullanılması öne çıkmaktadır (Şimşek, 2012)

\section{a) Hematopoetik kök hücreler}

Hematopoetik kök hücrelerin kaynağı, en çok erişkin kök hücrelerinin bulunduğu yer olan kemik iliğidir. Günümüzde bu hücrelerden birçok hastalığın tedavisinde yararlanılmaktadır.

Ancak kemik iliğindeki her 10-15 bin hücreden sadece biri hematopoetik kök hücre olarak kullanılırken, kordon kanında veya plasentadaki bu oran daha fazladır (Prockop, 1997).

(Hematopetik kök hücrelerin multipotent karakterde olması, kolay elde edilmesi ve hızlı çoğaltılabilmesi gibi avantajları diğer kök hücre türlerine göre daha fazla tercih edilme sebebi olarak gösterilmektedir (Yasuaki ve ark., 2010).

\section{b) Stromal kök hücreler}

Kemik iliği stromal kök hücrelerine mezenkimal kök hücre de denir (Prockop, 1997). Bu hücrelerin kemik, kıkırdak gibi birçok dokuya farklılaştı̆̆ı, karaciğer, sinoviyal sıvı, amniyon sıvısı, plasenta ve periferik kandan izole edilebildiği bildirilmektedir (Şenkal ve ark., 2011).

\section{c) Organlardaki kök hücreler}

$\mathrm{Bu}$ hücreler meydana gelen doku hasarı ya da ölümlerinde içinde bulundukları dokuyu tamir edebilme yeteneğine sahip, beyin, deri, kas, sindirim sistemi, kornea, retina, pankreas ve karaciğer gibi dokularda bulunan kök hücrelerdir (Şimşek 2012).

\section{Fötal kök hücreler}

Gebeliğin istemli ya da istemsiz olarak sonlanmasıyla elde edilen fötal dokudan, multipotent özellikteki kök hücreler ile pluripotent özellik taşıyan embriyonik üreme hücreleri ayrıştırılabilmektedir. Bu nedenle fötal kök hücreler, bilimsel çalışmalarda embriyonik kök hücrelerine alternatif olarak kullanılmaktadır (Meyer, 2000). Bu hücrelerin araştırma ve tedavide kullanımı etik 
açıdan ciddi sorunlara yol açabilmektedir. Ancak kendiliğinden düşük yapmış kişilerin gönüllü olarak bu hücrelerin kullanımına izin vermesi ile araştırma ve tedavi amacıyla kullanılabilmektedir. Tüm bu nedenlerden dolayı fötal kök hücrelerin tedavilerde kullanımı oldukça sınırlı düzeylerde seyretmektedir (Lisker, 2003).

\section{Veteriner Hekimlikte Kök Hücre Kullanımı}

Kök hücre çalışmalarının temel noktası, araştırma çalışmalarının sonucunda tedavi aşamalarında kullanımıdır. Bu tedavi pluripotent veya multipotent kök hücrelerinin hastalıklı ya da hasarlı dokuların yerine kullanılmasını kapsayan bir tedavi şeklidir. Aynı zamanda bu tarz hastalıkların tedavisine gen terapisi de eklenmektedir. Gen terapisinde, meydana gelen hasarda ya da bozuklukta oluşan bozuk genin kopyasının oluşturularak yedeklenmesi amaçlanmaktadır (Kruse ve ark., 2008).

Veteriner hekimlik alanında kök hücre tedavisi ilk olarak Herthel tarafından 1995 yılında atların ligament problemlerinde uygulanmıştır. Bu amaçla sternumdan elde edilen büyük hacimdeki saf kemik iliği doğrudan hasarlı ligament üzerine enjekte edilmiş, gerçekleştirilen uygulama sonrası geleneksel tedavi yöntemlerine kıyasla fonksiyonel iyileşme sağlandığı rapor edilmiştir. Yapılan çalışmalar sonucunda da kök hücre tedavilerinin kullanımı yaygınlaşmaya başlamıştır (Herthel, 2002).

Kök hücreler, kedi ve köpeklerde, kalp hastalıklarında, ortopedik lezyonlarda, tip I ve II diyabette, kıkırdak defektlerinde, merkezi sinir sistemi hastalıklarında, göz hastalıklarında ve tümöral olguların tedavisinde kullanılmaktadır. Atlarda tendinitis, ligament, eklem ve kıkırdak hasarlarının tedavisi ile büyükbaş hayvanlarda ortopedik hasarlar, deri lezyonları ve eklem hastalıklarında da kullanılmaktadır (Erol ve Arıcan, 2008).

Atlarda ligament, tendo ve eklem hasarlarında mezenkimal kök hücrelerin kullanımı başarılı sonuçlar vermektedir. Mezenkimal kök hücrelerin vücuttan izole edilmesi üç yöntemle gerçekleşmektedir (Schnabel ve ark., 2007). İlk yöntemde kemik iliğinden alınan örnekler çoğaltılarak konsantre kök hücre popülasyonları elde edilmekte, ikinci yöntemde kemik iliğinden alınan örnekler çoğaltılarak konsantre karışık kök hücre popülasyonları meydana getirilmektedir. Son yöntemde ise yağ dokudan elde edilen hücreler çoğaltılarak kök hücre popülasyonları oluşturulmaktadır. Üç yöntem sonucunda mezenkimal kök hücreler elde edilerek tedavide kullanılmaktadır (Schnabel ve ark., 2008).

Kemik iliği kaynaklı mezenkimal kök hücreler, kolay ve nispeten invaziv olmayan bir şekilde elde edilmekte ve diğer mezenkimal kök hücrelere kıyasla kas iskelet sistemi dokularına farklılaşma kapasitelerinin daha yüksek olduğu bildirilmektedir (Kisiday ve ark., 2008). Atlarda kemik iliği ve sternumdan, köpeklerde ise proksimal humerus veya femurdan elde edilmektedir. Alınan kemik iliğinden kök hücre meydana gelmesi için 3-6 haftalık bir sürece ihtiyaç vardır (Vidal ve ark., 2008).

Akut ve kronik tendinitisli, osteoarthritisli ve osteokondrotisli atlarda yapılan kök hücre çalışmaları başarılı sonuçlar vermiş, hastalığın nüks etme oranının düşük ve tedavi başarı yüzdesinin daha yüksek olduğu görülmüştür (Kisiday ve ark., 2008). Deneysel olarak yapılan klinik çalışmalarda, pluripotent veya fötal kök hücrelerin transplantasyonu ile omurilik hasarları, Pürkinje hücre dejenerasyonu, karaciğer ve kalp yetmezliği, kas distrofisi gibi çeşitli kronik hastalıkların tedavisinde kök hücre tedavilerinin başarılı sonuçlar verdiği bildirilmiştir (Yılmaz ve Uçar, 2006). Aynı şekilde iyileşme belirtisi göstermeyen ya da kırık hatlarının birbirinden uzak olduğu kemik kırıklarında, nonunion, malunion gibi kemik defektlerinde, mezenkimal kök hücrelerin etkili olduğu rapor edilmektedir (Udehiya ve ark., 2013). Dermatolojik hastalıklar açısından iyileşme belirtisi göstermeyen ya da çok yavaş iyileşme gösteren kronik yaraların tedavisinde mezenkimal kök hücrelerin kullanılmasının yara iyileşmesini hızlandırdığı bildirilmektedir (Das ve ark., 2012). Atopik dermatit gibi immun kökenli dermatalojik hastalıklarda, yara dokularında, nedeni belli olmayan alopesilerde mezenkimal kök hücrelerin etkili olduğu gösterilmiştir (Harman, 2013). Göz hastalıklarında, özellikle optik sinir hasarında, göz yanıklarında ve gözün tümoral olgularında, kök hücreler, tedavide başarılı bir şekilde kullanılmaktadır. Hematopoetik kök hücrelerin özellikle ulkus kornea gibi göz hastalıklarında etkili olduğu bildirilmektedir (Marfe ve ark., 2012).

\section{Sonuç}

Sonuç olarak veteriner hekimlik alanında yapılan çalışmalar göstermektedir ki kök hücrelerin veteriner hekimlik alanında kullanımı oldukça önemlidir. Günümüzde maliyetinin yüksek olması çiftlik hayvanlarında kullanımını kısıtlasa da özellikle yarışlarda kullanılan ve maddi değeri yüksek olan atların önemli sorunlardan biri olan ayak hastalıklarında kök hücre tedavilerinin olumlu sonuç verdiği bilinmektedir. Bunun yanında özellikle pet hayvanları ile insanlar arasında duygusal bağların gelişmesi pet hayvancılığının yaygınlaşmasına neden olmuştur. Birçok hasta sahibi tedavisi mümkün olmayan hastalıklara yakalanmış petleri için farklı 
çözüm yolları aramaktadır Kök hücrelerinin bu ve benzeri sebeplerle veteriner hekimlikte kullanımının yaygınlaşacağı düşünülmektedir. Bundan dolayı kök hücreleri ve bu hücrelerinin veteriner hekimlikte kullanım alanları ile ilgili bilgiye ihtiyaç duyulmaktadır. Hazırlamış olduğumuz bu derlemenin hem serbest veteriner hekimler hem de bu konuda çalışma yapmak isteyen araştırmacılar için ön bilgi kaynağı olacağı düşünülmektedir.

\section{Kaynaklar}

Bianco P, Cao X, Frenette PS, Mao JJ, Robey PG, Simmons PJ, Wang CY, 2013: The meaning, the sense and the significance: translating the science of mesenchymal stem cells into medicine. Nature Medicine, 19(1), 35-42.

Clevers $H, 2015$ : What is an adult stem cell? Science, 350(6266), 1319-1320.

Das J, Nath I, Kumardas R, Routray P, Behera SS, 2012: Autologous stem cell therapy to treat chronic ulcer in heifer- A case study. Vet World, 5(12), 771-774.

Erol H, Arıcan M, 2008: Atlarda Tendinitisin Kök Hücre ille Sağaltımı I: Kök Hücre Nedir ve Niçin Önemlidir? Veteriner Hekimliğinde Kullanım Alanları Nedir. Veteriner Cerrahi Derg, 14(2), 26-31.

Gattegno-Ho D, Argyle SA, Argyle DJ, 2012: Stem cells and veterinary medicine: Tools to understand diseases and enable tissue regeneration and drug discovery. The Vet J, 191, 19-27.

Harman RJ, 2013: Stem cell therapy in veterinary dermatology. Vet Dermatol 24, 90-124.

Herthel DJ, 2002: Suspensory desmitis therapies. Proc 12th ACVS Symp., 165-167.

Juopperi TA, 2012: Back to basics: Stem cells and veterinary medicine. The Vet J, 191, 139-140.

Kalra K and Tomar P.C, 2014: Stem Cell: Basics, Classification and Applications. AJPCT, 2(7), 919-930.

Karaşahin T, 2012: Review Articles Embriyonik Kök Hücreler. Erciyes Üniv Vet Fak Derg, 9(1), 65-71.

Kisiday JD, Kopesky PV, Evans CH, Grodzinky AJ, Mcwraith CW, Frisbie DD, 2008: Evoluation of Adult Equine Bone Marrow-and Adipose-Derived Progenitor Cell Chondrogenesis in Hydrogel Cultures. J Orthop Res 26, 322-331.

Kruse C, Danner D, Rapoport H, 2008: Current Stem Cell Technology: Limitations and Realistic Expectations. Eng Life Sci, 8(1), 13-18.

Lisker R, 2003: Ethical and Legal Issues in Therapeutic Cloning and the Study of Stem Cells. Arch Med Res, 34, 607-611.

Marfe G, Giordano MM, Ranallı M, Cozzoli E, Distefano C, Malafoglia V, Polettini M, Gambacurta A, 2012: Blood Derived Stem Cells: An Ameliorative Therapy in Veterinary Ophthalmology. J Cell Physiol, 227, 1250-1256.

Meyer JR, 2000: Human embryonic stem cells and respect for life. J Med Ethics, 26(3), 166-170.

Perin EC, Geng YJ, Willerson JT, 2003: Adult Stem Cell Therapy in Perspective. Circulation, 107, 935-938.
Prockop DJ, 1997: Marrow Stromal Cells As Stem Cells For Nonhematopoietic Tissues. Science, 276(5309), 71-4.

Sağsöz H, Ketani MA, 2008: Kök Hücreler. Dicle Üniv Vet Fak Derg, 1(2), 29-33.

Schnabel LV, Mohammed HO, Miller BJ, McDermott WG, Jacobson MS, Santangelo KS, Fortier LA, 2007: Platelet rich plasma (PRP) enhances anabolic gene expression patterns in flexor digitorum superficialis tendons. J Orthop Res, 25, 230-240.

Schnabel LV, Mohammed HO, Jacobson MS, Fortier LA, 2008: Effects of platelet rich plasma and acellular bone marrow on gene expression patterns and DNA content of equine suspensory ligament explant cultures. Equine Vet, 40, 260-265.

Şahin F, Saydam G, Omay SB, 2005: Kök Hücre Plastisitesi ve Klinik Pratikte Kök Hücre Tedavisi. UHOD, 15(1), 48-56.

Şenkal iV, Akyüz Ü, Yalnız F, Çiftçi F, Yurtsever A, 2011: Mezenkimal kök hücrelerin ratlarda crohn hastalığı modelinde doku hasarı, enflamatuar ve antienflamatuar sitokinlere etkisi. ist Tıp Fak Derg, 74(4), 59-63.

Şimşek Ö, 2012: Yetişkin Kök Hücrelerin Dünü ve Bugünü. Atatürk Üniversitesi Vet Bil Derg 7(3), 231-236.

Thomson JA, Eldor JI, Shapiro SS, Waknitz MA, Swiergiel JJ, Marshall VS, Jones JM, 1998: Embryonic Stem Cell Lines Derived from Human Blastocysts. Science, 282(5391), 1145-1147.

Thore $C B$, Sudheer $S$, Janke $D$, Jagodzinska J, Jung $M$, Adjaye J, 2008: The Origins of Human Embryonic Stem Cells: A Biological Conundrum. Cells Tissues Organs, 188, 9-22.

Udehiya RK, Amarpal, Aital HP, Kinjaydekar P, Pawde AM, Singh R, Sharma GT, 2013: Comparison of autogenic and allogenic bone marrow derived mesenchymal stem cells for repair of segmental bone defects in rabbits. Res Vet Sci, 94, 743752.

Ural AU, 2006: Kök Hücreler. TOTBID, 5, 140-145.

Vidal MA, Robinson SO, Lopez MJ, Paulsen DB, Borkhsenious O, Johnson JR, Moore RM, Gimble JM, 2008: Comparison of chondrogenic potential in equine mesenchymal stromal cells derived from adipose tissue and bone marrow. Vet Surg, 37, 713.

Webster RA, Blaber SP, Herbert BR, Wilkins MR and Vese G, 2012: The role of mesenchymal stem cells in veterinary therapeutics - a review. $N Z$ Vet J, 60(5), 265-272.

Yasuaki O, Yasuhide Y, Hiroe O, Mika T, Yoshihiro K, Mari S, Yoko K, Koji H, Shigeru S, Katsuhisa H, Shunsuke Y, Hajime O, 2010: Induction of pluripotent stem cells from human third molar mesenchymal stromal cells. J Biol Chem, 285, 29270-29278.

Yılmaz O, Uçar M, 2006: Kök hücre çalışmaları ve terapötik klonlama. Hayv Araş Derg, 16(1), 26-31.

${ }^{*}$ Yazışma adresi: Osman BULUT

Muğla Sıtkı Koçman Üniversitesi, Milas Veteriner

Fakültesi, Milas, Türkiye.

e-mail: obulut@mu.edu.tr 